Journal of Applied Pharmaceutical Science Vol. 5 (09), pp. 032-036, September, 2015

Available online at http://www.japsonline.com

DOI: $10.7324 / \mathrm{JAPS} .2015 .50906$

ISSN 2231-3354 (cc) BY-NC-SA

\title{
Chemical constituents of Cycas aenigma
}

\author{
Vincent Antonio S. $\mathrm{Ng}^{1}$, Esperanza Maribel G. Agoo ${ }^{2}$, Chien-Chang Shen ${ }^{3}$, Consolacion Y. Ragasa ${ }^{1,4^{*}}$ \\ ${ }^{1}$ Chemistry Department, De La Salle University 2401 Taft Avenue, Manila 1004, Philippines. ${ }^{2}$ Biology Department, De La Salle University 2401 Taft \\ Avenue, Manila 1004, Philippines. ${ }^{3}$ National Research Institute of Chinese Medicine, 155-1, Li-Nong St., Sec. 2, Taipei 112, Taiwan. ${ }^{4}$ Chemistry \\ Department, De La Salle University Science \& Technology Complex Leandro V. Locsin Campus, Binan City, Laguna 4024, Philippines.
}

\begin{tabular}{l} 
ARTICLE INFO \\
\hline Article history: \\
Received on: 28/05/2015 \\
Revised on: 18/06/2015 \\
Accepted on: 09/07/2015 \\
Available online: 27/09/2015 \\
\hline Key words: Cycas lacrimans, \\
Cycadaceae, 2-[2-hydroxy-5- \\
(3-hydroxypropyl)-3- \\
methoxyphenyl] -1-(4- \\
hydroxy-3-methoxyphenyl) \\
propane-1,3-diol, pinoresinol, \\
fatty alcohols, triacylglycerols, \\
$\beta$-sitosterol, stigmasterol
\end{tabular}

\section{INTRODUCTION}

Cycas resemble palms in morphology and are commonly called sago palm. They are considered as fossil plants though they may have evolved only about 12 million years ago (Nagalingum et al., 2011). They are widely distributed in the Tropics (Donaldson, 2003) where they grow on volcanic, limestone, ultramafic, sandy, or even water-logged soils in grassland and forest habitats (Madulid and Agoo, 2009). The demand of Cycas species for domestic and international horticultural trade, grassland and forest fires, and conversion of their natural habitats to settlements and other land uses have threatened to varying degrees the wild populations of the genus (IUCN, 2010). Some of these threatened species are $C$. curranii

\footnotetext{
* Corresponding Author

Email: consolacion.ragasa@dlsu.edu.ph
}

(Agoo et al., 2010), C. wadei (Hill, 2010) and C. zambalensis as Critically Endangered (CR) (Agoo et al., 2010), C. riuminiana as Endangered (E) (Agoo et al., 2010), and C. saxatilis as Vulnerable (V) (Bosenberg JD. 2010). There are no reported chemical and biological activity studies on $C$. aenigma. However, some Cycas species have been studied for their chemical constituents and biological activities. Cycasin, a carcinogenic toxin was isolated from the most studied Cycas species, $C$. revoluta Thunb. and $C$. circinalis L. (Nishida et al., 1955; Laqueur et al., 1963). Biflavonoids, lignans, flavan-3-ols, flavone-C-glucosides, norisoprenoids, and a flavanone were obtained from the methanolic extract of the leaflets of $C$. circinalis $\mathrm{L}$. and the chloroform extract of $C$. revoluta Thunb. Three of the biflavonoids exhibited moderate activity against $S$. aureus and methicillin-resistant $S$. aureus (Moawad et al., 2010). Moreover, the leaves of C. revoluta Thunb. and $C$. circinalis L. yielded lariciresinol, naringenin and biflavonoids (Ferreira et al, 2009). 
$\beta$-Sitosterol $\beta$-D-glucoside, stigmasterol $\beta$-D-glucoside, $\beta$-sitosterol, and stigmasterol were obtained from the seeds of $C$. micronesica K. D. Hill (Marler et al., 2006), while C. beddomei afforded a new biflavonoid, along with pinoresinol, hinokiflavone, and amento flavones (Das et al., 2006; Das et al., 2005). The leaves of $C$. panzhihuaensis yielded a new flavone, along with 2,3dihydrohinokiflavone, a biflavone, vanillic acid, sitosterol and daucosterol (Zhou et al., 2002). Chavicol $\beta$-rutinoside, amentoflavone, podocarpusflavone $\mathrm{A}$, a biflavone, $\beta$-sitosterol, daucosterol and palmitic acid were isolated from the methanolic extracts of the stems, flowers and seeds of $C$. panzhihuaensis $\mathrm{L}$. (Zhou et al., 1999). This study is part of our research on the chemical constituents of the genus Cycas. We earlier reported the isolation of squalene, $\beta$-sitosterol, stigmasterol, and triglycerides from the sarcotesta; $\beta$-sitosterol, stigmasterol, triglycerides and phytyl fatty acid esters from the endotesta; $\beta$-sitosterol, stigmasterol, and triglycerides, and $\beta$-sitosteryl fatty acid esters from the sclerotesta; and $\beta$-sitosteryl fatty acid esters from the bark of Cycas sancti-lasallei ( $\mathrm{Ng}$ et al., 2015). We report herein the isolation of 2-[2-hydroxy-5-(3-hydroxypropyl)-3methoxyphenyl]-1-(4-hydroxy-3 methoxyphenyl) propane-1,3-diol (1), pinoresinol (2), and fatty alcohol (3) from the leaflets; andtriglycerols (4), and a mixture of $\beta$-sitosterol (5a) and stigmasterol $(\mathbf{5 b})$ from the petiole and rachis. To the best of our knowledge this is the first report on the isolation of these compounds from Cycas aenigma.

\section{MATERIALS AND METHODS}

\section{General experimental procedure}

NMR spectra were recorded on a Varian VNMRS spectrometer in $\mathrm{CDCl}_{3}$ at $600 \mathrm{MHz}$ for ${ }^{1} \mathrm{H} \mathrm{NMR}$ and $150 \mathrm{MHz}$ for ${ }^{13} \mathrm{C}$ NMR spectra. Column chromatography was performed with silica gel 60 (70-230 mesh). Thin layer chromatography was performed with plastic backed plates coated with silica gel $\mathrm{F}_{254}$ and the plates were visualized by spraying with vanillin $/ \mathrm{H}_{2} \mathrm{SO}_{4}$ solution followed by warming.<smiles>COc1cc(C(O)C(CO)c2cc(CCCO)cc(OC)c2O)ccc1O</smiles>

1<smiles>COc1cc(C2OC[C@@H]3C(c4ccc(O)c(OC)c4)OC[C@@H]23)ccc1O</smiles>

2
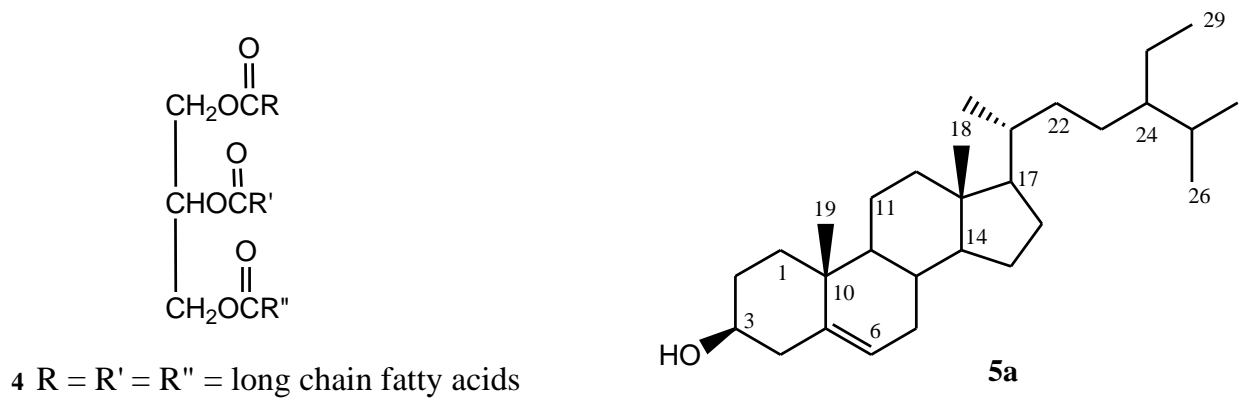<smiles>CCC(/C=C/[C@H](C)C1CCC2C3CC=C4C[C@@H](O)CC[C@]4(C)C3CC[C@@]21C)C(C)C</smiles> 


\section{Plant material}

Cycas aenigma leaflets and petiole and rachis were collected in 2013. Voucher specimens were collected and authenticated by one of the authors (EMGA) and deposited in the De La Salle University-Manila Herbarium (DLSUH).

\section{General isolation procedure}

A glass column 18 inches in height and 1.0 inch internal diameter was used for the chromatography of the crude extracts. Twenty milliliter fractions were collected. All fractions were monitored by thin layer chromatography. Fractions with spots of the same $R_{f}$ values were combined and rechromatographed in appropriate solvent systems until TLC pure isolates were obtained. A glass column 12 inches in height and 0.5 inch internal diameter was used for the rechromatography of smaller fractions from the first column. Five milliliter fractions were collected. Final purifications were conducted using Pasteur pipettes as columns. One milliliter fractions were collected.

\section{Isolation of the chemical constituents of the leaflets}

The air-dried bark of $C$. aenigma $(105 \mathrm{~g})$ were ground in a blender, soaked in $\mathrm{CH}_{2} \mathrm{Cl}_{2}$ for 3 days and then filtered. The solvent was evaporated under vacuum to afford a crude extract (2.3 g) which was chromatographed using increasing proportions of acetone in $\mathrm{CH}_{2} \mathrm{Cl}_{2}$ at $20 \%$ increment. The $20 \%$ acetone in $\mathrm{CH}_{2} \mathrm{Cl}_{2}$ fraction was rechromatographed $(2 \times)$ using $15 \%$ EtOAc in petroleum ether to afford $\mathbf{3}$ (3 $\mathrm{mg})$ after washing with petroleum ether.

The $80 \%$ acetone in $\mathrm{CH}_{2} \mathrm{Cl}_{2}$ fraction was rechromatographed $(4 \times)$ in $\mathrm{CH}_{3} \mathrm{CN}: \mathrm{Et}_{2} \mathrm{O}: \mathrm{CH}_{2} \mathrm{Cl}_{2} \quad(1: 1: 8$ by volume) to yield $2(9 \mathrm{mg})$ after trituration with petroleum ether. The $90 \%$ acetone in $\mathrm{CH}_{2} \mathrm{Cl}_{2}$ fraction was rechromatographed $(4 \times)$ using $\mathrm{CH}_{3} \mathrm{CN}: \mathrm{Et}_{2} \mathrm{O}: \mathrm{CH}_{2} \mathrm{Cl}_{2}(2.5: 2.5: 5, \mathrm{v} / \mathrm{v})$ to afford $1(12 \mathrm{mg})$ after trituration with petroleum ether.

\section{Isolation of the chemical constituents of the petiole and rachis}

The air-dried petiole and rachis of C. aenigma (47 g) were ground in a blender, soaked in $\mathrm{CH}_{2} \mathrm{Cl}_{2}$ for 3 days and then filtered. The solvent was evaporated under vacuum to afford a crude extract $(0.7 \mathrm{~g})$ which was chromatographed using increasing proportions of acetone in $\mathrm{CH}_{2} \mathrm{Cl}_{2}$ at $10 \%$ increment. The $20 \%$ acetone in $\mathrm{CH}_{2} \mathrm{Cl}_{2}$ fraction was rechromatographed $(4 \times)$ using $7.5 \%$ EtOAc in petroleum ether to yield 4 (8 mg). The $30 \%$ acetone in $\mathrm{CH}_{2} \mathrm{Cl}_{2}$ fraction was rechromatographed using $15 \%$ EtOAc in petroleum ether to afford a mixture of $\mathbf{5} \mathbf{a}$ and $\mathbf{5 b}$ in a 1:1 ratio $(4 \mathrm{mg})$ after washing with petroleum ether.

\section{2-[2-Hydroxy-5-(3-hydroxypropyl)-3-methoxyphenyl]-1-(4- hydroxy-3-methoxyphenyl)propane -1,3-diol (1)}

${ }^{1} \mathrm{H}-\mathrm{NMR}\left(600 \mathrm{MHz}, \mathrm{CDCl}_{3}\right): \delta 6.92(1 \mathrm{H}, \mathrm{d}, J=1.8 \mathrm{~Hz}$, H-2), $6.86(1 \mathrm{H}, \mathrm{d}, J=8.5 \mathrm{~Hz}, \mathrm{H}-5), 6.90(1 \mathrm{H}, \mathrm{dd}, J=7.8,1.8 \mathrm{~Hz}$, H-6), 5.53 (1H, d, J = 7.2 Hz, H-7), 3.59 (1H, m, H-8), 3.89 (1H, $\mathrm{dd}, J=10.8,4.8 \mathrm{~Hz}, \mathrm{H}-9), 3.95(1 \mathrm{H}, \mathrm{dd}, J=10.8,6 \mathrm{~Hz}, \mathrm{H}-9), 6.66$ (1H, s, H-4'), 6.67 (1H, s, H-6'), 2.66 (2H, t, J=7.2 Hz, $\left.\mathrm{CH}_{2}-7^{\prime}\right)$, $1.88\left(2 \mathrm{H}, \mathrm{m}, \mathrm{CH}_{2}-8^{\prime}\right), 3.68\left(2 \mathrm{H}, \mathrm{t}, J=6.6 \mathrm{~Hz}, \mathrm{CH}_{2}-9^{\prime}\right), 3.85(3 \mathrm{H}, \mathrm{s}$, 3- $\left.\mathrm{OCH}_{3}\right), 3.87\left(3 \mathrm{H}, \mathrm{s}, 3 \mathrm{-}-\mathrm{OCH}_{3}\right) ;{ }^{13} \mathrm{C} \mathrm{NMR}\left(150 \mathrm{MHz}, \mathrm{CDCl}_{3}\right): \delta$ 133.08 (C-1), 108.79 (C-2), 146.62 (C-3), 145.61 (C-4), 114.25 (C5), 119.43 (C-6), 87.88 (C-7), 53.79 (C-8), 63.91 (C-9), 127.66 (C1'), 146.56 (C-2'), 144.20 (C-3'), 115.89 (C-4'), 135.41 (C-5'), 112.43 (C-6'), 32.01 (C-7'), 34.64 (C-8'), 62.32 (C-9'), 55.98, 55.99 (3- $\left.-\mathrm{OCH}_{3}, 3^{\prime}-\mathrm{OCH}_{3}\right)$.

\section{Pinoresinol (2)}

${ }^{1} \mathrm{H}$ NMR $\left(600 \mathrm{MHz}, \mathrm{CDCl}_{3}\right): \delta 4.72(1 \mathrm{H}, \mathrm{d}, J=4.2 \mathrm{~Hz}$, $\mathrm{H}-1), 3.08$ (1H, dd, $J=4.8,6.6 \mathrm{~Hz}, \mathrm{H}-2), 3.86(1 \mathrm{H}, \mathrm{dd}, J=3.6,9.0$ $\mathrm{Hz}, \mathrm{H}-3), 4.25$ (1H, dd, $J=7.2,9.0 \mathrm{~Hz}, \mathrm{H}-3), 6.89(1 \mathrm{H}, \mathrm{d}, J=1.8$, H-2'), 6.89 (1H, d, $\left.J=6.6, \mathrm{H}^{-5}\right), 6.82(1 \mathrm{H}, \mathrm{dd}, J=7.8,1.8 \mathrm{~Hz}, \mathrm{H}-$ $\left.6^{\prime}\right), 3.91\left(3 \mathrm{H}, \mathrm{s},-\mathrm{OCH}_{3}\right) ;{ }^{13} \mathrm{C} \mathrm{NMR}\left(150 \mathrm{MHz}, \mathrm{CDCl}_{3}\right): \delta 85.86(\mathrm{C}-$ 1), 54.16 (C-2), 71.66 (C-3), 132.91 (C-1'), 108.56 (C-2'), 146.68 $\left(\mathrm{C}-3^{\prime}\right), 145.22$ (C-4'), 114.23 (C-5'), 118.96 (C-6'), 55.95 (3'$\left.\mathrm{OCH}_{3}\right)$.

\section{Fatty Alcohols (3)}

${ }^{1} \mathrm{H}$ NMR $\left(600 \mathrm{MHz}, \mathrm{CDCl}_{3}\right): \delta 3.56(\mathrm{t}, J=7.2 \mathrm{~Hz}$, terminal $\mathrm{CH}_{2} \mathrm{OH}$ ), 2.00 (allylic $\mathrm{CH}_{2}$ ), 1.56 (m, $\alpha-\mathrm{CH}_{2}$ ), 1.23-1.34 (br s, $\left.\mathrm{CH}_{2}\right), 0.86\left(\mathrm{t}, J=7.2 \mathrm{~Hz}\right.$, terminal $\left.\mathrm{CH}_{3}\right) ;{ }^{13} \mathrm{C} \mathrm{NMR}(150$ $\mathrm{MHz}, \mathrm{CDCl}_{3}$ ): $\delta 72.04$ (C-1), 37.48, 31.92, 31.89, 29.70, 29.68, $29.66,29.63,29.62,29.57,29.36,29.32,25.64,22.69,22.68$ $\left(\mathrm{CH}_{2}\right)_{\mathrm{n}}, 14.12\left(\mathrm{CH}_{3}\right)$.

\section{Triacylglycerols (4)}

${ }^{1} \mathrm{H}$ NMR $\left(600 \mathrm{MHz}, \mathrm{CDCl}_{3}\right): \delta 4.28(2 \mathrm{H}, \mathrm{dd}, J=4.2$, $12.0 \mathrm{~Hz}$, glyceryl $\left.\mathrm{CH}_{2} \mathrm{O}\right), 4.12(2 \mathrm{H}, \mathrm{dd}, J=6.0,12.0 \mathrm{~Hz}$, glyceryl $\left.\mathrm{CH}_{2} \mathrm{O}\right), 5.32(1 \mathrm{H}, \mathrm{m}$, glyceryl $\mathrm{CHO}), 2.31(6 \mathrm{H}, \mathrm{t}, J=7.5 \mathrm{~Hz}, \alpha-$ $\mathrm{CH}_{2}$ ), 5.33 (m, olefinic $\mathrm{H}$ ), 2.75 (double allylic $\mathrm{CH}_{2}$ ), 1.98-2.05 (allylic, $\left.\mathrm{CH}_{2}\right), 1.23-1.35\left(\mathrm{CH}_{2}\right), 0.87\left(\mathrm{t}, J=6.6 \mathrm{~Hz}, \mathrm{CH}_{3}\right) ;{ }^{13} \mathrm{C}$ NMR (150 MHz, $\mathrm{CDCl}_{3}$ ): $\delta 62.09$ (glyceryl $\mathrm{CH}_{2}$ ), 68.87 (glyceryl $\mathrm{CH}), 173.26,173.30(\mathrm{C}=\mathrm{O} \alpha), 172.84(\mathrm{C}=\mathrm{O} \beta), 34.02,34.05$, 34.19 (C-2), 24.83, 24.86 (C-3), 29.05, 29.08, 29.12 (C-4), 29.18, 29.20, 29.27 (C-5), 29.48 (C-6), 22.57, 22.69 (C-8), 130.23, 130.01, 129.70 (C-9), 127.89, 128.06, 129.68 (C-10), 25.62, 27.17, $27.19,27.22,29.32,29.34,29.36,29.52,29.62,29.66,29.70$, $29.76\left(\mathrm{CH}_{2}\right), 31.52,31.90,31.92\left(\mathrm{CH}_{2}\right), 14.07,14.12$ (terminal $\left.\mathrm{CH}_{3}\right)$.

\section{B-Sitosterol (5a)}

${ }^{13} \mathrm{C}$ NMR (150 MHz, $\left.\mathrm{CDCl}_{3}\right): \delta 37.2(\mathrm{C}-1), 31.7(\mathrm{C}-2)$, 71.8 (C-3), 42.3 (C-4), 140.7 (C-5), 121.7 (C-6), 31.9(C-7), 31.9 (C-8), 50.1 (C-9), 36.5 (C-10), 21.1 (C-11), 39.8 (C-12), 42.3 (C13), 56.8(C-14), 24.3 (C-15), 28.2 (C-16), 56.0 (C-17), 12.0 (C18), 19.4 (C-19), 36.1 (C-20), 18.8 (C-21), 33.9 (C-22), 26.0 (C23), 45.8 (C-24), 29.1 (C-25), 19.0 (C-26), 19.8 (C-27), 23.0 (C28), 11.9 (C-29).

\section{Stigmasterol (5b)}

${ }^{13} \mathrm{C}$ NMR $\left(150 \mathrm{MHz}, \mathrm{CDCl}_{3}\right): \delta 37.2(\mathrm{C}-1), 31.7(\mathrm{C}-2)$, 71.8 (C-3), 42.3 (C-4), 140.7 (C-5), 121.7 (C-6), 31.9 (C-7), 31.9 (C-8), 50.1 (C-9), 36.5 (C-10), 21.1 (C-11), 39.8 (C-12), 42.3 (C- 
13), 56.8 (C-14), 24.3 (C-15), 29.1 (C-16), 56.0 (C-17), 12.0 (C18), 19.4 (C-19), 40.5 (C-20), 21.1 (C-21), 138.3 (C-22), 129.3 (C23), 51.2 (C-24), 31.9 (C-25), 21.1 (C-26), 19.0 (C-27), 25.4 (C28), 12.1 (C-29).

\section{RESULTS AND DISCUSSION}

Silica gel chromatography of the dichloromethane extracts of C. aenigma yielded 1-3 from the leaves; and 4-5b from the petiole and rachis. The structure of $\mathbf{1}$ was elucidated by extensive 1D and 2D NMR spectroscopy and confirmed by comparison of its NMR data with those reported in the literature for 2-[2-hydroxy-5-(3-hydroxypropyl)-3-methoxyphenyl]-1-(4hydroxy-3-methoxyphenyl)propane-1,3-diol (1) (Koyama et al., 2006). Compounds $\mathbf{2 - 5}$ b were identified by comparison of their NMR data with those reported in the literature for pinoresinol (2) (Ragasa et al., 2000), fatty alcohols (3) (Ragasa et al., 2014a), triglycerides (4) (Ragasa et al., 2015), $\beta$-sitosterol (5a) (Ragasa et al., 2014b), and stigmasterol (5b) (Jamal et al., 2008).

2-[2-Hydroxy-5-(3-hydroxypropyl)-3-methoxyphenyl]-1(4-hydroxy-3-methoxyphenyl)propane-1,3-diol (1) was first reported as a constituent of Taxus yunnanensis (Koyama et al., 2008). This neolignan was tested for inhibitory effects on induced histamine release from the human basophilic cell line, KU812. Results showed that $\mathbf{1}$ did not exhibit any antiallergic activity at a $1.5 \mu \mathrm{g} / \mathrm{ml}$ concentration (Koyama et al., 2008). On the other hand, pinoresinol (2) was found to have antioxidant and $\mathrm{Ca}^{2+}$ antagonist properties (Páska et al., 2002). It was reported to exhibit strong antiinflammatory properties by acting on the NF- $\kappa \mathrm{B}$ signaling pathway (During et al, 2012). Furthermore, $\mathbf{2}$ attenuates inflammatory responses of microglia and could be useful in modulation of inflammatory status in brain disorders (Jung et al., 2010). Lignan 2 was shown to possess fungicidal activities and therapeutic potential as an antifungal agent for the treatment of fungal infectious diseases in humans (Hwang et al., 2010). It exhibited inhibitory activity against rat intestinal maltase with an $\mathrm{IC}_{50}$ value of $34.3 \mu \mathrm{M}$ (Wikul et al., 2012). Long-chain fatty alcohols (3) were reported to exhibit a protective effect on some mediators involved in the inflammatory damage development (Fernandez-Arche et al., 2015). On the other hand, triacylglycerides (4) exhibited antimicrobial activity against S. aureus, P. aeruginosa, B. subtilis, C. albicans, and $T$. mentagrophytes (Ragasa et al., 2013). Another study reported that 4 showed a direct relationship between toxicity and increasing unsaturation, which in turn correlated with increasing susceptibility to oxidation (Ferruzzi and Blakeslee, 2007). $\beta$ Sitosterol (5a) was observed to have growth inhibitory effects on human breast MCF-7 and MDA-MB-231 adenocarcinoma cells (Awad et al., 2007). It was shown to be effective for the treatment of benign prostatic hyperplasia (Jayaprakasha et al., 2007). Compound 5a was also reported to attenuate $\beta$-catenin and PCNA expression, as well as quench radical in vitro, making it a potential anticancer drug for colon carcinogenesis (Baskar et al., 2010). It can inhibit the expression of NPC1L1 in the enterocytes to reduce intestinal cholesterol uptake (Jesch et al., 2009). It was reported to induce apoptosis mediated by the activation of ERK and the down-regulation of Akt in MCA-102 murine fibrosarcoma cells (Moon et al., 2007). On the other hand, stigmasterol (5b) shows therapeutic efficacy against Ehrlich ascites carcinoma bearing mice while conferring protection against cancer induced altered physiological conditions (Ghosh et al., 2011). Compound 5b lowers plasma cholesterol levels, inhibits intestinal cholesterol and plant sterol absorption, and suppresses hepatic cholesterol and classic bile acid synthesis in Winstar as well as WKY rats (Batta et al., 2006). Other studies reported that 5b showed cytostatic activity against Hep-2 and McCoy cells (Gómez et al., 2001), markedly inhibited tumour promotion in two stage carcinogenesis experiments (Kasahara et al., 1994), and exhibited antimutagenic (Lim et al., 2005), topical anti-inflammatory (García et al., 1999), antiosteoarthritic (Gabay et al., 2010) and antioxidant (Panda et al., 2009) activities.

\section{CONCLUSION}

The dichloromethane extracts of Cycas aenigma, a plant endemic to the Philippines with no reported chemical and biological activity studies, afforded a rare neolignan, 2-[2hydroxy-5-(3-hydroxypropyl)-3-methoxyphenyl]-1-(4-hydroxy-3methoxyphenyl)propane-1,3-diol(1), pinoresinol (2), fatty alcohols (3),triacylglycerols (4), $\beta$-sitosterol (5a), and stigmasterol (5b). Compounds 2-5b were reported to exhibit diverse biological activities.

\section{ACKNOWLEDGEMENT}

A research grant from the Commission on Higher Education-Philippine Higher Education Research Network (CHED-PHERNet) of the Philippines is gratefully acknowledged.

\section{REFERENCES}

Agoo EMG, Madulid DA, Linis VC, Sambale E. In: IUCN 2010. IUCN Red List of Threatened Species. Version 2013.2. <www.iucnredlist.org>. Downloaded on 16 December 2013.

Awad AB, Chinnman M, Fink CS, Bradford PG. $\beta$-Sitosterol activates Fas signaling in human breast cancer cells. Phytomed 2007; $14: 747-754$

Baskar AA, Ignacimuthu S, Paulraj G, Numair K. Chemopreventive potential of $\beta$-sitosterol in experimental colon cancer model-an in vitro and in vivo study. BMC Comp Alt Med 2010; 10:24.

Batta AK, Xu G, Honda A, Miyazaki T, Salen G. Stigmasterol reduces plasma cholesterol levels and inhibits hepatic synthesis and intestinal absorption in the rat. Metabolism 2006; 55(3):292-299.

Bosenberg JD. 2010. In: IUCN 2013. IUCN Red List of Threatened Species. Version 2013.2. <www.iucnredlist.org>. Downloaded on 16 December 2013

Das B, Mahender G, Rao YK, Thirupathi P. A new biflavonoid from Cycas beddomei. Indian J Chem Sec B 2006; 45B:1933-1935.

Das B, Mahender G, Rao YK, Prabhakar A, Jagadeesh B. Biflavonoids from Cycas beddomei. Chem Pharm Bull 2005; 53:135-136.

Donaldson JS, Cycads. 2003. Status Survey and Conservation Action Plan. IUCN Gland, Switzerland and Cambridge, U.K. 
During A, Debouche C, Raas T, Larondelle Y. Among plant lignans, pinoresinol has the strongest antiinflammatory properties in human intestinal Caco-2 cells. J Nutr 2012; 142(10):1798-1805.

Fernandez-Arche A, Marquez-Martin A, De La Puerta Vazquez R, Perona JS, Terencio C, Perez-Camino C, Ruiz-Gutierrez V. Long-chain fatty alcohols from pomace olive oil modulate therelease of proinflammatory mediators. Downloaded from digital.csic.es/bitstream/ 10261/55289/3/Pro-inflammatory.pdf on May 20, 2015.

Ferreira D, Zjawiony JK, Moawad A, Hifnawy M, Hetta M. Chemical investigation of two species of the family Cycadaceae. Planta Med 2009; 75:P-53.

Ferruzzi MG, Blakeslee J. Digestion, absorption, and cancer preventative activity of dietary chlorophyll derivatives. Nutr Res 2007; 27:1-12.

Gabay O, Sanchez C, Salvat C, Chevy F, Breton M, Nourissat G. Stigmasterol: a phytosterol with potential anti-osteoarthritic properties. Osteoarth Cartilage 2010; 18(1):106-116.

García MD, Sáenz MT, Gómez MA, Fernández MA. Topical anti-inflammatory activity of phytosterols isolated from Eryngium foetidumon chronic and acute inflammation models. Phytother Res 1999; 13(1):78-80.

Ghosh T, Maity TK, Singh J. Evaluation of antitumor activity of stigmasterol, a constituent isolated from Bacopa monnieri Linn aerial parts against ehrlich ascites carcinoma in mice. Orient Pharm Exp Med 2011; 11:41-49.

Gómez MA, García MD, Sáenz MT. Cytostatic activity of Achillea ageratum L. Phytother Res 2001; 15(7):633-634.

Hill KD. 2010. Cycas wadei. In: IUCN 2013. IUCN Red List of Threatened Species. Version 2013.2. 〈www.iucnredlist.org>. Downloaded on 26 December 2013.

Hwang B, Lee J, Liu Q-H, Woo E-R, Lee DG. Antifungal effect of (+)-pinoresinol isolated from Sambucus williamsii. Molecules 2010; 15(5):3507-3516.

In: IUCN 2010. IUCN Red List of Threatened Species. Version 2010.4. <www.iucnredlist.org>. (Downloaded on 09 February 2011).

Jamal AK, Yaacob WA, Din LB. A chemical study on Phyllanthus reticulates. J Phys Sci 2008; 19(2):45-50.

Jayaprakasha GK, Mandadi KK, Poulose SM, Jadegoud Y, Gowda GA, Patil BS. Inhibition of colon cancer growth and antioxidant activity of bioactive compounds from Poncirus trifoliate (L.) Raf. Bioorg Med Chem 2007; 15:4923-4932.

Jesch ED, Seo JM, Carr TP, Lee JY. Sitosterol reduces messenger RNA and protein expression levels of Niemann-Pick C1-like 1 in FHs 74 Int cells. Nutr Res 2009; 29(12):859-866.

Jung HW, Mahesh R, Lee JG, Lee SH, Kim YS, Park Y-K. Pinoresinol from the fruits of Forsythia koreana inhibits inflammatory responses in LPS-activated microglia. Neurosci Lett 2010; 480(3):215220.

Kasahara Y, Kumaki K, Katagiri S, Yasukawa K, Yamanouchi S, Takido M. Carthami flos extract and its component, stigmasterol, inhibit tumour promotion in mouse skin two-stage carcinogenesis. Phytother Res 1994; 8(6):327-331.

Koyama J, Morita I, Kobayashi N, Hirai K, Simamura E, Nobukawa A, Kadota S. Antiallergic activity of aqueous extracts and constituents of Taxus yunnanensis. Biol Pharm Bull 2006; 29(11):23102312 .

Laqueur GL, Mickelsen O, Whiting MG, Kurlad LT. Carcinogenic properties of nuts from Cycas Circinalis L. indigenous to Guam. J Natl Cancer Inst 1963; 31:919-951.
Lim J-C, Park JH, Budesinsky M, Kasal A, Han Y-H, Koo B-S, Lee S-I, Lee D-U. Antimutagenic constituents from the thorns of Gleditsia sinensis. Chem Pharm Bull 2005; 53(5):561-564.

Madulid DA, Agoo EMG. Taxonomy and conservation of Philippine Cycads. Blumea 2009; 54:99-102.

Marler TA, Lee V, Chung J, Shaw CA. Steryl glucoside concentration declines with Cycas micronesica seed age. Funcl Plant Biol 2006; 33:857-862.

Moawad A, Hetta M, Zjawiony JK, Jacob MR, Hifnawy M, Marais JP, Ferreira D. Phytochemical investigation of Cycas circinalis and Cycas revoluta leaflets: moderately active antibacterial biflavonoids. Planta Med 2010; 76:796-802.

Moon DO, Lee KJ, Choi YH, Kim GY. $\beta$-Sitosterol-inducedapoptosis is mediated by the activation of ERK and the downregulation of Akt in MCA-102 murine fibrosarcoma cells. Int Immunopharmacol 2007; 7:1044-1053.

Nagalingum NS, Marshal CR, Quental TB, Tai HS, Little DP, Matthews S. Recent synchronous radiation of a living fossil. Science 2011; 334:796-799.

$\mathrm{Ng}$ VAS, Agoo EM, Shen CC, Ragasa CY. Chemical constituents of Cycas sancti-lasallei. J Appl Pharm Sci 2015; 5(Suppl 1):12-17.

Nishida K, Kobayashi A, Nagahama T. Cycasin, a new toxic glycoside of Cycas revoluta Thunb. I. Isolation and structure of cycasin. Bull Agric Chem Soc Japan 1955; 19:77-84.

Panda S, Jafri M, Kar A, Meheta BK. Thyroid inhibitory, antiperoxidative and hypoglycemic effects of stigmasterol, isolated from Butea monosperma. Fitoter 2009; 80(2):123-126.

Páska C, Innocenti G, Ferlin M, Kunvári M, László M. Pinoresinol from Ipomoea cairica cell cultures. Nat Prod Lett 2002; 16(5):359-63.

Ragasa CY, Hofilena JG, Rideout JA. Lignans from Gliricidia sepium. ACGC Chem Res Commun 2000; 10:52-60.

Ragasa CY, Torres OB, Mandia EH, Shen C-C. Chemical constituents of Terminalia microcarpa. Der Pharmacia Lettre 2014a; 6(6):439-442.

Ragasa CY, Ng VAS, De Los Reyes MM, Mandia EH, Oyong GG, Shen C-C. Chemical constituents and cytotoxicity of the leaves of Dysoxylum gaudichaudianum (A. Juss.) Miq. Der Pharma Chemica. 2014b; 6(5):182-187.

Ragasa CY, Lorena GS, Mandia EH, Raga DD, Shen C-C. Chemical constituents of Abrus precatorius. Amer J Essent Oils Nat Prod 2013; 1(2):7-10.

Wikul A, Damsud T, Kataoka K, Phuwapraisirisan P. (+)Pinoresinol is a putative hypoglycemic agent in defatted sesame (Sesamum indicum) seeds though inhibiting $\alpha$-glucosidase. Bioorg Med Chem Lett 2012; 22(16):5215-5217.

Zhou Y, Peng S-L, Li C-L, Wang M-K, Ding L-S. A new Cglucosylflavone from the leaves of Cycas panzhihuaensis. Acta Bot Sin 2002; 44:101-103.

Zhou Y, Zhang X, Jiang S, Li C, Peng S. Chemical constituents of Cycas panzhihuaensis. Chin J Appl Environ Biol 1999; 5:367-370.

\section{How to cite this article:}

Vincent Antonio Ng, Esperanza Maribel Agoo, Chien-Chang Shen, Consolacion Y. Ragasa. Chemical constituents of Cycas aenigma. J App Pharm Sci, 2015; 5 (09): 032-036. 